\title{
Přičinnost
}

\section{a prirozenost}

\section{v hippokratovských}

\section{spisech}

CAUSALITY AND NATURE IN

THE HIPPOCRATIC TREATISES

\section{PAVEL hOBzA}

Filosofický ústav AV ČR, v. v. i.

Jilská 1

11000 Praha 1

pavel_hobza@hotmail.com

\section{ABSTRAKT}

In my paper I am dealing with the problem when and in what form the notion of causality appeared in ancient Greece. It is mostly assumed that already the Presocratics (even the Milesians) dealt with causes. However, none of the extant Presocratic fragments mentions the Greek term for cause (aitia or aition), which is why we should look for the origin of the conception of causality elsewhere. The elaborate conception of causality is to be found in the Corpus Hippocraticum, whose oldest texts originate from the second half of the fifth century B. C. As the close analysis of the Hippocratic treatise On the Sacred Disease suggests, here we find a very complex causal theory articulated by means of the concept phusis. Although there are few occurrences of the term phusis in the Presocratics, they used it only in the common meaning "true nature", not referring to its etymology, i.e. "growth". By exploiting its etymological implications the Hippocratic authors were able to conceive of it as a fundamental causal factor. 
Ve svém př́spěvku se chci věnovat tomu, kdy a v jaké podobě se v Řecku objevuje koncepce prř́činnosti. Většinou se předpokládá, že se př́ičinami zabývali již předsókratici, ba již Múlétané, nicméně o tom se nám nedochovaly žádné přímé doklady. ${ }^{1}$ Pokud příčinu definujeme - zhruba řečeno - jako působení něčeho na něco, ${ }^{2}$ mohlo by se zdát, že

1 Aristotelés sice například v Metafyzice říká, že již Mílétané měli zjevně (délon) hovořit o přičinách, nicméně Aristotelés nahliží předchůdce prizmatem své specifické koncepce čtyř přičin (srv. Met. I,3 983a33-b6), přičemž Mílétanům připisuje pouze látkovou přičinu (srv. Met. I,3 983b6-8; Met. 1,3 983b18-21). At tak či onak, od Mílétanů se nám nedochovaly žádné přimé doklady. A ani u ostatních předsókratiků nemáme pojem aitia doložený. K Aristotelovu interpretačnímu přistupu srv. Hobza 2015.

2 Srv. Frede 1987, s. 125-126: “We might even find it misleading to talk of Aristotelian koncepce přičin se musela vyskytovat přinejmenším u Empedoklea a Anaxagory, kteří hovoří o tom, že láska a svár,

causes and wonder whether in translating the relevant passages in Aristotle we should not avoid the term 'cause' altogether. For an end, a form, or matter do not seem to be the right kinds of items to cause anything, let alone to be causes. [...] Quite generally our use of causal terms seems to be strongly coloured by the notion that in causation there is something which in some sense does something or other so as to produce or bring about an effect. [...] It is only with Aristotle's moving cause that we think that we readily understand why it should be called a cause. But it would be a mistake to think that Aristotle with his notion of a moving cause tried to capture our notion of cause or at least a notion we would readily recognize as a notion of cause, though it is significant that people have tended to think that among the Aristotelian causes it is only the moving cause which is a cause really." 
respektive mysl nějak působí na směs prvotních prvků. ${ }^{3}$ Žádný z těchto myslitelů však o příčinách explicitně nehovoří, respektive nepoužívá pojmy aitia či to aition (jejichž prostřednictvím se v pozdější filosofické řečtině - například u Platóna či Aristotela - běžně označují příčiny). ${ }^{4}$ Proto je třeba spíš předpokládat,

3 Srv. DK 31 B 17; DK 59 B 12.

4 V návaznosti na jednu pasáž z Platónova dialogu Faidón (srv. Phd. 95e-105c) se někdy rozlišuje význam pojmů to aition a aitia. Zatímco termín to aition (jedná se o substantivizované adjektivum) označuje určitou věc, událost či faktor, zkrátka něco, co chápeme jako „přičinu“, aitia odkazuje spíš k něčemu, co má propoziční obsah, a znamená tedy spíš „vysvětlení“, „kauzální vysvětlení“ či „explanatorní příčinu“. K významu aitia srv. Vlastos 1969, s. 292-296 ("On the Meaning of AITIA"); Burge 1971, s. 2-4 ("The meaning of 'aitia'"). I když v ostatních textech není toto rozlišení zdaleka tak jasné (koneckonců ani v dialogu Faidón není zcela jednoznačné), například Hankinson se domnívá, že je ho třeba při zkoumání řeckého myšlení zohledňovat, srv. Hankinson 1998, s. 4: "I have deliberately vacillated between talking of causes and of explanations. The two ideas are clearly connected: when we explain something, we generally give reasons for its being the way it is; and to give reasons why something is the way it is frequently involves an account of the causes of that thing. Conversely, by specifying the causes of some event or state of affairs, we are inclined to think that we have gone at least some of the way towards explaining it. But for all that, the two concepts are different, even if closely related: and a good deal turns exegetically on whether one chooses to render the Greek word aition (or aitia) as 'cause', 'reason', or 'explanation'. Causes are actual items, events, agents, facts, states of affairs; explanations, on the other hand, are propositional." Pro účely našeho zkoumání však není toto přisné rozlišování mezi přičinou a vysvětlením důležité. Snažíme se totiž pouze zjistit, jak se v Řecku ustavila teoretická že k rozpracování koncepce příčinnosti došlo jinde než u předsókratiků.

Explicitní a propracovanou koncepci příčinnosti doprovázenou hojným užíváním pojmu příčina (aitia, to aition) můžeme vcelku přesně situovat. Lze se s ní setkat ve spisech hippokratovských lékařů, které se souhrnně označují jako Corpus Hippocraticum. I když není jejich datace jistá, většinou se předpokládá, že nejstarší pocházejí z druhé poloviny, či spíše poslední třetiny 5. století př. n. $1 .^{5}$

Ve svém příspěvku se zaměřím především na zkoumání hippokratovského spisu $O$ svaté nemoci, který velmi názorně ukazuje, jak hippokratovští autoři příčinnost pojímali. Abychom ovšem jejich koncepci náležitě docenili, bude dobré zasadit celou problematiku příčinnosti do širšího kontextu, jehož důležitou součást představují homérské eposy.

\section{AITIOS A HOMÉRSKÉ POJETÍ „PŘíčINNOSTI“}

V homérských eposech se o příčinách nehovoří. To ovšem není nijak překvapivé,

koncepce přičinnosti, přičemž nezáleží ani tak na tom, zda se jedná pouze o stanovení jednotlivých působících faktorů, anebo o vysvětlení takového působení. Navíc - jak jsme naznačili - ve většině dochovaných textů nelze takové rozlišení jednoznačně prokázat. Srv. Frede 1987, s. 128: "Now it is true that at least from the fifth century B.C. onward such prepositional items, too, come to be called causes, aitia. But throughout antiquity, as far as I can see, it is non-propositional items like Aristotle's causes which are referred to when causes are discussed systematically."

5 K obecné charakteristice hippokratovských spisů srv. Jones 1923a; Fischerová 2012. 
uvážíme-li, že se jedná o nejstarší dochované řecké texty, které vznikly dlouho předtím, než se u Mílét’anů objevily první zárodky filosofického či vědeckého pohledu na svět, a které jsou proto výrazem myticko-náboženské zkušenosti. I když se u Homéra nevyskytuje ani substantivum aitia, ani substantivizované adjektivum to aition, můžeme zde nalézt alespoň adjektivum aitios, z něhož jsou oba termíny znamenající př́ičinu odvozeny. Slovo aitios bylo původně používáno v morálně-právním smyslu k označení viny, provinění či odpovědnosti. Achilleus například Agamemnónovým poslům, kteří mu mají odvést Bríseovnu a kteří z něj mají pochopitelně strach, říká, že oni nejsou vinni (epaitioi), ${ }^{6}$ vinný je pouze Agamemnón. Když Priamos přihlíží z výšky svého sídla nástupu řeckých vojsk, vybízí Helenu, aby si k němu přisedla a řekla mu, jak se ten který Řek jmenuje; přitom ji hned ujišţuje, že za válku není zodpovědná či vinna (aitié) ona, nýbrž odpovědní (aitioi) jsou bohové. ${ }^{7}$

Jestliže se v homérských textech nevyskytuje pojem př́čcina a adjektivum aitios mělo původně pouze morální význam a nijak nesouviselo s přírodním děním (v jehož rámci jsme jinak zvyklí hovořit o příčinách), znamená to snad, že lidé v homérské době neměli žádnou představu o tom, co to je příčina, respektive co dnes považujeme za příčinu? Takový závěr by byl poněkud přehnaný. Určitou obecnou představou příčinnosti, respektive toho, že jedna

\footnotetext{
$6 \quad$ Il. I,335.

7 Il. III,164-165.
}

událost podmiňuje či vyvolává druhou, disponují všichni lidé bez ohledu na to, v které době či kultuře žijí. Například žádný zemědělec by asi nepředpokládal, že sklidí úrodu, aniž by zasel. Žádný lovec by se zase nedomníval, že uloví nějakou kořist, když na ni nebude mířit či když nebude vynakládat určité úsilí a um, aby ji ulovil. ${ }^{8}$ Ani v Řecku homérského období tomu nebylo jinak. Pro homérské, značně mytické myšlení je ovšem typické, že mnohé události, které bychom dnes vysvětlovali pomocí přirozených příčin, jsou chápány jako božský zásah.

Vhomérských básních se sice nepracuje s pojmem př́ičina (což vzhledem k básnicko-mytickému charakteru daného textu není nijak překvapivé), nicméně rozhodně se nezdá, že by homérští Řekové neměli představu žádného „příčinného" působení jedné věci na druhou, byṫ toto působení často považovali za božský zásah. A právě toto božské působení je pro naše zkoumání obzvlášt důležité, nebot' je mnohdy popisováno prostřednictvím adjektiva aitios („vinný, odpovědný“). Morálně-právní konotace tohoto termínu mohly původně působit na to, aby byly jeho prostřednictvím popisovány pouze neočekávané, abnormální, ba nepřirozené události. Jestliže se něco děje očekávatelně či přirozeně, nežádá si to v očích homérského člověka

Srv. Lloyd 1979, s. 49-50: “Yet an assumption of the regularity of natural phenomena is implicit in much of human behaviour. [...] To understand, let alone to learn from, experience at all presupposes some idea of the regularity of phenomena, although that idea may well be neither explicit nor universalised." 
žádné vysvětlení. Vysvětlit je třeba naopak vždy to, co vykazuje nějakou abnormalitu (at' již se jedná o fyzickou, či psychickou událost).${ }^{9}$ A protože se takové vysvětlení nachází většinou v božském zásahu (tedy v zásahu určitého individualizovaného aktéra), je božský činitel často pojímán v morálně-právním smyslu jako ten, kdo je odpovědný či vinný (aitios).

\section{VYSVĚTLENI SVATÉ NEMOCI}

Zatímco homérský člověk hledá vysvětlení či příčinu pouze tehdy, dojde-li k narušení přirozeného či očekávatelného průběhu nějaké události, pro běžné pojetí prríčinnosti, jak se konstituovalo ve filosofické, případně vědecké tradici, je naopak charakteristické, že se snaží vysvětlit spíš to, co se děje přirozeně (v protikladu vůči homérskému pojetí můžeme hovořit o standardním pojetí př́íčinnosti). Jinými slovy, příčiny se nehledají - alespoň nikoli primárně u toho, co se jeví jako zvláštní, neočekávané či nepřirozené, nýbrž mají spíš vysvětlit přirozené fungování světa.

Rozchod s homérským pojetím příčinnosti lze velmi dobře a názorně doložit v hippokratovském spise $O$ svaté nemoci. ${ }^{10}$ Takzvanou svatou nemocí má

Srv. Dodds 2000, s. 27-28: „V závěrečném shrnutí lze konstatovat, že veškeré odchylky od normálního lidského chování, jejichž přičiny se bezprostředně nevysvětlí tak, že si je uvědomí subjekt sám nebo je postřehnou jiní, jsou přičítány nadpřirozenému působení, stejně jako každá odchylka od obvyklého ,chování počasí nebo tětivy."

10 Spisy hippokratovského corpusu jsou tematicky, obsahově i stylisticky značně různorodé. Kromě specializovaných autor tohoto spisu na mysli nejenom to, co bychom na základě dnešní lékařské taxonomie označili v úzkém smyslu za epilepsii, nýbrž patrně i jiné podoby náhlých nekontrolovatelných záchvatů (například hysterie, panické záchvaty atd.). Jak vyplývá z prvních čtyř kapitol, ještě koncem 5. století př. n. l., kdy byl tento spis napsán, připisovala většina Řeků tyto (epileptické či jiné) záchvaty běžně zásahu nějakého božstva. ${ }^{11}$

odborných textů, jaké představuji různé lékařské kazuistiky či anatomické popisy lidského těla, zde nacházíme rétoricky vybroušené texty, které původně sloužily $\mathrm{k}$ ústnímu veřejnému přednášení. Jouanna identifikuje skupinu devíti takových rétoricky propracovaných textů, mezi něž radí i spis O svaté nemoci (Jouanna 1984, s. 29-31). Protože tyto texty byly určeny pro širší publikum, neIze vyloučit, že jejich styl a terminologie odpovídaji spíš dobové rétorické praxi než vlastní lékařské reflexi. Na druhou stranu Jouanna i tuto skupinu rozděluje do dvou podskupin podle toho, zda se jedná o orální didaktickou promluvu ("l'exposé oral didactique"), anebo o orální epideiktickou řeč („l'exposé oral épidictique“) (tamt., s. 32). Zatímco u epideiktických řečí, které byly určeny především pro laické publikum a mezi něž se radí spisy $O$ umění a $O$ vzduchu a dechu, nelze vyloučit, že byly napsány rétorem či sofistou (srv. Klouda 2012), didaktické promluvy, mezi něž patři i spis $O$ svaté nemoci, představovaly spišs specializované přednášky určené pro odbornou veřejnost; proto je pravděpodobné, že byly psány lékaři, kteři se svůj styl pokoušeli přizpůsobit dobové rétorické praxi (srv. Jouanna 2003b, s. X-XIII). I když by $\mathrm{i} v$ tomto připadě bylo možné argumentovat, že jejich terminologie a argumentace mohly být ovlivněny rétorickými potřebami a požadavky, domnívám se, že jsou spiš výrazem vlastní lékařské či vědecké reflexe.

11 K dobovým myšlenkovým představám, $\mathrm{k}$ obecné charakteristice a $\mathrm{k}$ relevanci tohoto spisu z hlediska řeckého myšlení 
Podobnost se zásahy homérských bohů je zjevná. Podobně jako v případě činů homérských bohů objevuje se i svatá nemoc náhle a neočekávaně. Cíl, který si autor tohoto spisu klade, je ukázat, že svatou nemoc nelze vysvětlovat svévolným zásahem (antropomorfního, ba zlovolného) božstva, nýbrž že podobně jako ostatní nemoci vzniká na základě přirozených příčin. Tento cíl, který je vlastně autorovým programem či manifestem, je velmi pregnantně vyjádřen hned na počátku celého spisu:

\section{1 „[Tato takzvaná svatá nemoc] se mi} nezdá božštější ani světější než jiné nemoci. Jako ostatní má sice přirozenost (fysis) a příčinu (profasis), nicméně lidé ji považují za božský zásah/čin (theion ti prégma) kvůli vlastní nezkušenosti a kvůli tomu, že se jeví jako podivná, nebot' se nepodobá ostatním nemocem." ${ }^{12,13}$

srv. Lloyd 1979, s. 10-58 ("The criticism of magic and the inquiry concerning nature"). K jeho dataci srv. Jones 1923b, s. 134 .

12 Dochovaný řecký text první části tohoto úryvku je poněkud nejistý. Grensemann a Jouanna, kteři v poslední době vydali své edice tohoto hippokratovského spisu, rekonstruují řecký text této pasáže shodně

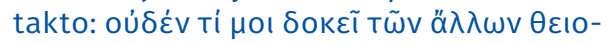

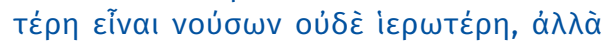

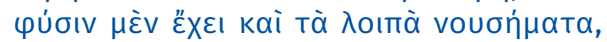

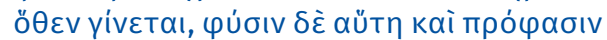
(srv. Grensemann 1968, s. 60; Hippokratés 2003 , s. 2). Poněkud odlišně konstruuje řecký text Littré (srv. Hippokratés 1849, s. 352) i Jones (srv. Hippokratés 1923b, s. 138). Tváři tvář této textové nejednoznačnosti Jones v poznámce k řeckému textu jednoduše konstatuje: "I am sure that the received text is wrong." (tamt., s. 139) Navzdory této textové nejistotě je ovšem podle něj hlavní myšlenka víceméně jasná: “Whatever the correct
Autor zde (na počátku celého spisu) vyrukuje rovnou s jednoznačným, takřka programovým prohlášením, že svatá nemoc není výsledkem božského zásahu či činu (theion ti prégma) ${ }^{14}$, nýbrž že má

reading may be, and this is uncertain, the sense of the passage is perfectly clear." (tamt., s. 139) Text tohoto místa je takřka totožný s pozdější pasáži, kterou budeme citovat pod číslem 4. Proto je možné, že při přepisování došlo k tomu, že se písař snažil prizpůsobit jednu pasáž druhé, a to i za cenu určitých doplnění či glos. Spolu s Jonesem se domnívám, že obrat tà 入oı-

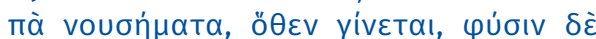

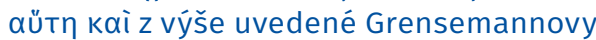
a Jouannovy rekonstrukce představuje glosu, která sem byla vložena na základě předpokládané analogie s úryvkem 4, a proto ji vypouštím. Částici de, která se v glose nachází a která by měla odpovídat předcházející částici men u slova fysis, posouvám spolu s Jonesem až do následující věty, srv. hoi de anthrópoi („nicméně lidé“). (Pro úplnost jen poznamenejme, že Grensemann dává celou výše uvedenou řeckou větu do závorek, pokládaje ji za pozdější vsuvku vytvořenou podle pasáže 4.)

13 Morb. Sacr. 1,2-7. Není-li uvedeno jinak, číslování kapitol a řádků hippokratovských spisů odkazuje na Jonesovo vydání hippokratovských spisů (srv. Hippokratés 1923a, 1923b, 1958).

14 Pragma, respektive iónsky prégma má sice většinou neurčitý význam „věc“, nicméně původně znamenalo spíš právě „čin, skutek“; je totiž odvozeno od slovesa prassó („jednám, konám“) (srv. LSJ, I). Také většina interpretů chápe termín prégma na tomto místě $v$ neosobním či neutrálním smyslu jako „věc“; např. Hippokratés 1849, s. 353: „quelque chose de divin“; Hippokratés 1923b, s. 139: „divine origin“. Taková interpretace by však byla nejen poněkud zavádějící, nýbrž vposled i rozporná. Jestliže se totiž v první větě tohoto úryvku říká, že svatá nemoc je stejně božská jako ostatní nemoci, pak není jasné, proč by vzápětí byla tato teze zpochybňována poukazem, že ji za cosi božského (za božskou věc) považuji pouze obyčejní lidé na základě nezkušenosti. Jak ještě uvidíme, kontrast, který zde má autor 
podobně jako ostatní nemoci vlastní přirozenost a příčinu. I přes téměř naturalistickou dikci tohoto prohlášení nelze autora považovat za naturalistu či ateistu v dnešním smyslu. Jak totiž říká hned v první větě, svatá nemoc není ani božštější, ani světější než ostatní nemoci, což znamená, že i ostatní nemoci jsou podle něj v jistém smyslu božské (proč je považuje za božské, naznačíme níže). ${ }^{15}$ Jinými slovy, autorův primární záměr není svatou nemoc nijak desakralizovat či naturalizovat, nýbrž ukázat, že není způsobena žádným individuálním, ba zlovolným božským zásahem/ činem (theion ti prégma). Proto se autor nepouští hned do zkoumání její přirozenosti a př́ičiny, ale první část svého spisu věnuje polemice s různými mágy ( $m a$ goi), očištovači (kathartai), potulnými kněžími (agyrtai) a šarlatány (alazones), kteří podle jeho názoru tuto nemoc jako první prohlásili za svatou (hierósantes), aby ji svými očištovacími praktikami (katharmoi) a zaříkáváními (epaoides)

na mysli, není kontrastem mezi jakousi naturalistickou přirozeností na jedné straně, a božskostí na straně druhé, nýbrž mezi (řekněme) skutečnou božskostí a lidově pojímanou božskostí spočivající na osobním či svévolném aktu nějakého boha. Kromě tohoto věcného argumentu svědči ještě jeden důvod pro to, že zde slovo prégma znamená „čin, skutek“. O něco niže $v$ textu je totiž toto slovo použito opět ve významu „čin“. Poté, co autor našeho textu kritizuje různé mágy a šarlatány za to, že k léčení svaté nemoci použivají očištovací praktiky a zaříkávání, konstatuje, že takto dělají nejbezbožnější čin (anosiótaton te kai atheótaton prégma poieúsin, Morb. Sacr. 4,34-35).

K interpretaci božského pojetí nemocí, respektive obecně náboženského či teologického charakteru spisu o svaté nemoci srv. Eijk 2005. mohli léčit. ${ }^{16}$ Příznačné je, že se náš autor nesnaží pouze ukázat, že tyto očištovací a zaříkávací praktiky jsou neúčinné, nýbrž že dokonce představují ten vůbec nejbezbožnější čin (anosiótaton te kai atheótaton prégma). ${ }^{17}$ Pokud by totiž svatou nemoc způsobovali skutečně bohové a různí mágové či očištovači by ji svými zaříkáváními mohli léčit, znamenalo by to, že by božská moc (tú theiú hé dynamis) byla ovládána a podřízena lidskému úsudku; vposled by se tak již nejednalo o nic božského (ti theion), nýbrž pouze lidského (anthrópinon). ${ }^{18}$ Vždyt' jak by mohlo být něco božského podrobeno lidskému působení, aniž by to neztratilo svou božskost?

Pro naše zkoumání je tato část spisu O svaté nemoci relevantní potud, pokud se zde v souvislosti s údajně božským zásahem či činem (respektive s domnělou schopností bohů způsobovat svatou nemoc) opakovaně používá adjektivum aitios $\mathrm{v}$ jeho původně morálně-právním významu „vinný, odpovědný“, jak jsme se s ním setkali u Homéra (nově se zde objevuje i odvozené substantivum aitié, které sice $\mathrm{v}$ hippokratovských spisech běžně znamená „příčina“, nicméně zde má ještě původní morální význam „vina, odpovědnost“). Autor uvádí poměrně rozsáhlý seznam, v němž - jak to bylo v jeho době asi obvyklé - jednotlivé podoby (hekaston eidos) svaté nemoci připisuje působení různých bohů (tato různorodost podob svaté nemoci naznačuje, že ji nelze jednoduše identifikovat

\footnotetext{
16 Morb. Sacr. 1,1-13.

17 Morb. Sacr. 4,34-35.

18 Morb. Sacr. 4,13-16.
} 
s epilepsií v tom smyslu, jak ji pojímá dnešní medicína). Poté, co vždy uvede konkrétní podobu svaté nemoci, říká, který z bohů se za ni považuje zodpovědný či vinný (aitios), případně kterému bohu se připisuje vina či odpovědnost (aitié) za danou podobu záchvatu. ${ }^{19}$

Čím jasněji si uvědomíme, že ještě koncem 5. století př. n. l. byl za „příčinu“ božské nemoci běžně považován zásah nějakého boha, tím efektivněji, odvážněji a inovativněji bude působit autorovo lakonické tvrzení ze začátku šesté kapitoly, že je za ni ve skutečnosti odpovědný (aitios) lidský mozek. Je přitom nápadné a signifikantní, že k vyjádření kauzální závislosti svaté nemoci na mozku používá autor stejné adjektivum, pomocí něhož se v lidových představách od dob Homéra popisoval svévolný zásah bohů. Nicméně je třeba pochopit, jak přesně mozek svatou nemoc zapř́íčiňuje. Pouhá aplikace původně morálního adjektiva aitios na nějaký přirozený fenomén (třeba mozek) by totiž sama o sobě nebyla zase až tak zásadní a revoluční; podobně tento termín používal například i Herodotos, když odmítal názor, že by za záplavy Nilu byly zodpovědné (aitioi) sezónní větry. ${ }^{20}$ Podívejme se proto, jak přesně hippokratovský autor pojímá příčinnost mozku.

2 „Tento stav zapříčiňuje (aitios) mozek, podobně jako i ostatní vážné nemoci. Jakým způsobem (hotó tropó) a z jaké příčiny (ex hoiés profasios) vzniká, jasně vysvětlím." ${ }^{21}$

\footnotetext{
19 Morb. Sacr. 4,20-33.

20 Hdt. II,20.

21 Morb. Sacr. 6,1-4; srv. též 20,28-29.
}

Z autorova konstatování, že jasně vysvětlí způsob (tropos) a příčinu (profasis) vzniku svaté nemoci, je zjevné, že příčinnost (aitios) mozku úzce souvisí s tímto vysvětlením a že bez něj by kauzální role mozku byla neúplná či alespoň nejasná (připomeňme, že termín profasis se v hippokratovských spisech, případně i u Thukydida, běžně používá k označení příčiny, ${ }^{22}$ nicméně později, již u Platóna a Aristotela, byl nahrazen pojmem aitia či to aition). ${ }^{23}$ Jinými slovy, o příčinnosti mozku nelze hovořit bez rozpoznání jejího průběhu (srv. „jakým způsobem vzniká") a bezprostřední příčiny (profasis). A tomuto vysvětlení je věnován víceméně zbytek spisu.

Autor nejprve konstatuje, že svatá nemoc se vyskytuje pouze $u$ jednoho ze dvou základních typů lidí, totiž u těch, kteří jsou hlenovití (flegmatódés), a nikoli žlučovití (cholódés), ${ }^{24}$ což

\section{Srv. Kirkwood 1952.}

23 Především v souvislosti s touto pasáží se někdy odlišuji termíny aitios a profasis. Zatímco profasis má označovat vnější kauzální faktor, aitios zase souvisí spíš s vnitřní či nutnou podmínkou. Jak uvidíme níže, ve spise $O$ svaté nemoci je toto rozlišení víceméně pouze nominální; navíc by ho bylo možné jen sotva prokázat v ostatních hippokratovských spisech. Srv. Lloyd 1979, s. 54, především pozn. 231; Eijk 2005, s. 54, především pozn. 24.

24 Je pravděpodobné, že teorie dvou štáv, jak se nachází ve spise $O$ svaté nemoci, představuje nejstarši podobu hippokratovské humorální teorie a že další štávy byly doplněny později, srv. Lonie 1981 s. 58-60. Klasickou humorální teorii sestávající ze čtyř základních tělesných štáv (krve, hlenu, žluté a černé žluči) lze v rámci hippokratovského corpusu nalézt ovšem pouze ve spise $O$ prirozenosti člověka. K přehledu různých možností, jak hippokratovští autoři chápali člověka (respektive z kolika a jakých konstituentů 
mimochodem pokládá za jeden $\mathrm{z}$ důkazů, že svatá nemoc není způsobena svévolným zásahem žádného boha; bůh by totiž mohl postihovat stejně či rovnoměrně oba typy lidí. ${ }^{25}$ Protože se obě konstituce předávají z rodičů na děti, je i svatá nemoc vlastně dědičná (kata ge$n o s)^{26}$. I když postihuje pouze hlenovité jedince, neznamená to, že by se musela projevit u všech hlenovitých typů. Její výskyt je totiž podmíněn celou řadou dalších kauzálních faktorů (profasies). Epileptické či jiné záchvaty vznikají v důsledku výtoku hlenu, který je nahromaděn v mozku, do cév (v tomto smyslu lze hovořit o příčinnosti mozku). Proto hippokratovský autor načrtává hned zkraje svou představu o vaskulárním systému, která je založena na tom, že v těle existují dvě hlavní cévy vedoucí do mozku. Podle jeho představ vedou cévy nejenom krev, nýbrž i vzduch. ${ }^{27}$ Když z mozku vyteče hlen do cév, omezí se, nebo se dokonce úplně zastaví distribuce vzduchu po těle. A protože vzduch souvisí s rozumem (fronésis) a s pohybem (kinésis), narušení jeho distribuce má vážné důsledky, může způsobit i bezvědomí. ${ }^{28}$

Pokud jde o vysvětlení svaté nemoci (o pochopení jejího "mechanismu“ a toho, kdo jí bude přesně trpět), sleduje autor její původ až do embryonálního stadia. Doslova říká, že začíná růst (fyestai) v embryu. Při vývoji embrya v matčině

je složen), srv. Fischerová 2012, s. 52-54; Bartoš 2008, s. 18-19; srv. též kapitolu IV.

Morb. Sacr. 5,15-21.

Morb. Sacr. 5,8.

Srv. Morb. Sacr. 6-7.

Morb. Sacr. 10,23-27. děloze dochází k tomu, že se mozek (jakož i ostatní orgány) očištuje od hlenu. Pokud toto očištění proběhne v pořádku (kalós kai metriós), bude člověk nejzdravější. Může se však stát, že odteče příliš mnoho nebo příliš málo hlenu anebo že hlen odteče až po narození. Nejhorší ovšem je, když se tělo od hlenu neočistí vůbec a hlen se usadí v mozku. Pak se stane hlenovitým. A právě u takových lidí se projevuje svatá nemoc. ${ }^{29}$ Pokud se totiž mozek od hlenu nevyčistil před narozením ani bezprostředně po něm, může během života docházet k náhlému uvolnění hlenu z mozku do cév, což má vzhledem k narušení distribuce vzduchu po těle nejrůznější důsledky: například zrychlený tlukot srdce, dýchavičnost nebo právě epileptický záchvat se všemi jeho příznaky, jako jsou dušení, pěna u úst, křeče, vyvrácené oči atd. ${ }^{30}$

To, zda, kdy a v jakém množství se hlen z mozku uvolní a jaké to bude mít přesně důsledky, záleží na celé řadě různých faktorů - například na věku (u malých dětí bývá epilepsie často smrtelná), na roční době, respektive na teplotě a na její prudké změně (rizikovým obdobím je především zima, kdy dochází k častému přecházení z tepla do chladu a naopak), na změně větrů (jižní vítr, který přináší či způsobuje vlhkost, je nejrizikovější) ${ }^{31}$ a samozřejmě - jak bývá u většiny hippokratovských lékařů zvykem - na životosprávě (diaité), která zahrnuje nejenom stravu, ale i fyzickou aktivitu, spánek atd. a která představuje

29 Morb. Sacr. 8.

30 Srv. Morb. Sacr. 9-10.

31 Srv. Morb. Sacr. 11-16. 
jediný prostředek, jak svatou nemoc léčit, případně jak jí předcházet. ${ }^{32}$

Nuže, teprve nyní na základě pochopení toho, jak podle hippokratovského autora božská nemoc přesně funguje, můžeme náležitě docenit jeho zjištění, že ji zapříčiňuje (aitios) mozek (2). Jestliže byl v lidových představách označován jako aitios (odpovědný či vinný) nějaký bůh, znamenalo to, že bůh byl považován za nutnou i dostatečnou podmínku dané události či jednání (kromě božského zásahu nebylo třeba hledat žádné další vysvětlení). Naproti tomu v hippokratovském konstatování, že mozek je aitios svaté nemoci, představuje mozek pouze její nutnou podmínku - bez mozku (respektive bez výtoku hlenu nahromaděného $v$ mozku do cév) by svatá nemoc se všemi svými specifickými nekontrolovatelnými projevy neexistovala. Mozek však nepředstavuje její dostatečnou podmínku. Mozek ji totiž sám o sobě nezpůsobuje. Jeho hlenovitý charakter (respektive výtok hlenu do cév) je ovlivněn celou řadou na mozku nezávislých faktorů, jako jsou vývoj embrya, teplo, chlad, změna větrů, životospráva atd. Jinými slovy, kdyby mozek nebyl ovlivňován celou řadou různých kauzálních faktorů (prafasis), které epileptický či jiný záchvat bud' přímo vyvolávají, nebo alespoň určují jeho přesnou podobu a intenzitu, svatá nemoc by nemohla vzniknout.

To, že je role mozku ve vysvětlení svaté nemoci značně omezená, vlastně pouze jaksi zprostředkovatelská (nebot je podmíněna dalšími faktory), sice ve srovnání s dřívější úlohou bohů (jakožto těch, kdo jsou považováni za původce určité události či jednání) značně limituje jeho kauzální možnosti, nicméně pokud jde o samotnou koncepci př́činnosti, je prohlášení mozku za „viníka“ (aitios) svaté nemoci zcela zásadní a revoluční. Mezi mozkem jakožto bezprostřední či nutnou příčinou (aitios) svaté nemoci a ostatními kauzálními faktory (profasies) dochází totiž k velmi komplexní interakci, která pouze při určité konstelaci vyvolá svatou nemoc (například působení tepla na hlenovitý mozek, které by jinak vyvolalo epileptický záchvat, může být eliminováno správnou životosprávou atd.). A právě tuto souhru a podmíněnost nejrůznějších kauzálních faktorů lze považovat za doklad toho, že se zde setkáváme s explicitní a propracovanou koncepcí příčinnosti. Navíc zprostředkovatelská funkce mozku ukazuje, že hippokratovský autor nepracuje pouze s představou bezprostředního působení něčeho na něco (jak to bylo běžné u Homéra anebo v případě lásky a sváru u Empedoklea či u Anaxagorovy mysli), nýbrž na základě důkladné (byt' samozřejmě z hlediska dnešních vědomostí poněkud fantastické) znalosti „mechanismu“ či fungování svaté nemoci předpokládá něco, co bychom mohli označit za kauzální řetězec, v jehož rámci určité faktory (profasies) působí na mozek, který teprve na základě jejich působení vyvolává určitou reakci, respektive zapř́íčiňuje (aitios) epileptický záchvat.

Bez ohledu na to, zda budeme ve spise $O$ svaté nemoci rozlišovat termíny 
aitios a profasis (například v tom smyslu, že zatímco aitios je nutná podmínka svaté nemoci, profasis dostatečná, případně že zatímco aitios souvisí s vnitřními faktory, profasis s vnějšími ${ }^{33}$ ), $\mathrm{z}$ historického hlediska je důležité především to, že se zde lze setkat s velmi komplexní teorií příčinnosti, v jejímž rámci na sebe působí různé kauzální faktory, které se různě podmiňují, vyvažují, eliminují, nebo naopak posilují. Jinými slovy, určitý efekt nemůže být automaticky vyvolán jediným faktorem, nýbrž pouze jejich komplexní souhrou. V tomto smyslu můžeme původní homérský termín aitios $\mathrm{v}$ autorově zjištění, že mozek je aitios svaté nemoci, interpretovat jednoduše jako příčinu, nebot' mozek se svou specifickou hlenovitou konstitucí představuje pouze jeden $\mathrm{z}$ mnoha kauzálních faktorů „zodpovědných“ za vznik svaté nemoci. (Z hlediska teorie př́ičinnosti je tedy rozlišení termínů aitios a profasis spíš pouze nominální, aniž by mělo nějakou věcnou relevanci.)

Tento aspekt zdůrazňuje například Hankinson, srv. Hankinson 1998, s. 55: "The writer of the Sacred Disease distinguishes between the internal structure of a disease and what occasions it [...]. The Hippocratic writers are the first explicitly to distinguish between those internal, constitutional factors which render some people more susceptible to particular diseases than others, and the external triggering causes which set the pathogenic process in motion. This coincides with the emergence of the goal of explanatory generality: the rationalist wants to know why it is that diseases affect some people and not others, and why some recover but others do not. Such concerns are practical, but they also involve an abstract desire to render the world intelligible."

\section{PŘIROZENOST SVATÉ}

NEMOCI

Poté, co jsme načrtli, jak hippokratovský autor pojímá příčinnost (tedy jako poměrně komplikovanou souhru vzájemně se podmiňujících faktorů), je třeba zamyslet se ještě jednou nad tím, co znamená, že mozek je příčinou svaté nemoci. Jak jsme viděli, mozek jako takový ji nezpůsobuje. Svatá nemoc se totiž objevuje pouze u lidí, jejichž mozek se bud' před narozením, anebo těsně po něm neočistil od hlenu a kteří jsou v důsledku toho nutně hlenovití. ${ }^{34}$ Takový hlenovitý mozek je ovšem jistým způsobem poškozený či narušený (srv. „poškození“ (diafthoré)). ${ }^{35}$ Pro naše zkoumání je důležité pochopit, jak (na základě jakého kritéria) je možné konstatovat, že je mozek narušený. Jak vyplývá z poslední části spisu, v níž se hovoří o tom, jaké psychické projevy s mozkem souvisejí, má mozek určitou fysis neboli přirozenost. ${ }^{36}$ Doslova se zde říká:

\footnotetext{
34 Morb. Sacr. 8.

35 Morb. Sacr. 18,1-2.

36 I když se termín fysis do češtiny běžně překládá dvěma způsoby (jednak jako „prrirozenost“ a jednak jako „prriroda“), kolektivní význam „příroda“ jakožto souhrn přirozeně existujících věcí se v 5. století př. n. l. (tedy v době, kterou se nyní zabýváme) vyskytoval pouze sporadicky, pokud vůbec (některé výskyty v hippokratovských spisech by snad mohly být interpretovány tímto způsobem, nicméně textová evidence není vůbec jednoznačná). Jak ještě uvidíme, teprve ve 4. století př. n. l. u Platóna a Aristotela se Ize setkat s kolektivním významem fysis zhruba odpovídajícím našemu pojmu „příroda“. Názornou shrnující charakteristiku významů fysis u předsókratovských a hippokratovských autorů podává Thein
} 
3 „Všemi těmito věcmi [tj. různými úzkostmi a fobiemi] trpíme kvůli mozku, pokud není zdráv, ale je teplejší, chladnější, vlhčí či sušší, než je jeho přirozenost (fysis), anebo proti přirozenosti (para tén fysin) trpí nějakým jiným nezvyklým stavem." ${ }^{\text {37 }}$

Jestliže má mozek nějakou přirozenost, která je úzce spjata se zdravím a od které se může mozek toho kterého konkrétního jedince odchylovat (at̉ již proto, že je teplejší, chladnější, vlhčí, sušší či jinak narušený), naznačuje to, že přirozenost mozku je normativní koncepce založená na jeho předpokládaném správném fungování. ${ }^{38}$ Aby totiž

2012, s. 32-33: „Veškeré významy slova fysis se totiž pohybuji mezi dvěma krajními a do značné míry opačnými póly: fysis pojmenovává na jedné straně neprůhledný vnitřek individuálních věcí, na druhé straně jejich společný a nejzazší vnějšek, jímž je osnova celku světa. [...] Napětí mezi jasnou vnějši odlišností jednotlivých věcí a jejich skrytými čili nezjevnými vlastnostmi se pak přenáší do hypotézy o určující roli skrytých vlastností, v nichž lze díky jejich možné a neverifikovatelné spřizněnosti se stejně nezjevným celkem světa hledat důvody a přičiny toho, proč se věci liší, ale přesto se chovají podle určitých pravidel a zákonů.“

37 Morb. Sacr. 17,14-18.

38 Srv. Bartoš 2008, s. 11: „Normativní koncept přirozeného, zdravého stavu je nutným předpokladem jakékoli lékařské teorie, a proto nedílnou součástí tehdejšího lékařství byl i výzkum lidské přirozenosti.“ I když Bartoš hovoři predevším o lidské prrirozenosti, platí jeho tvrzení i pro přirozenost jako takovou; koneckonců představě lidské přirozenosti (případně přirozenosti člověka či těla) musel - logicky i chronologicky - předcházet náhled do přirozenosti jednotlivých orgánů, respektive částí těla. K lidské přirozenosti srv. následující kapitolu IV. mohl vysvětlit svatou nemoc (případně další závažné nemoci, které jsou rovněž většinou spjaty s mozkem), musí náš autor nejprve předpokládat jakousi pravou či ideální povahu mozku. To mu umožní, aby různé nemoci vysvětloval jako odchylky od jeho správného fungování neboli přirozenosti. Za příčinu svaté nemoci nelze tedy pokládat mozek sám o sobě (jak to naznačoval úryvek 2), nýbrž spíš jeho (předpokládanou) přirozenost. To ovšem znamená, že fysis jakožto přirozenost představuje důležitý kauzální faktor svaté nemoci. Zdá se tedy, že to byla právě koncepce fysis, co umožnilo našemu hippokratovskému autorovi rozpracovat výše naznačené pojetí příčinnosti jakožto velmi komplexní souhry různých kauzálních faktorů.

Na tomto místě by bylo možné samozřejmě hned namítnout, že na základě jediné (byṫ jakkoli důležité) pasáže nelze činit tak zásadní hodnocení ohledně role pojmu fysis jakožto důležitého kauzálního faktoru. To je samozřejmě pravda, nicméně kdyby se prokázalo, že pojem fysis hraje ve spise $O$ svaténemoci, ba v celém hippokratovském corpusu důležitou úlohu (a nejedná se tedy pouze o jeho nahodilé a výjimečné užití), nebylo by to vůbec nepravděpodobné. Proto se podívejme na to, zda autor spisu $O$ svaté nemoci používá pojem fysis ještě i na jiných místech a viných souvislostech než ve spojení s mozkem (případně s jiným tělesným orgánem).

Jak jsme viděli v úryvku 1, pocházejícím hned ze začátku celého spisu, náš autor nehovoří pouze o přirozenosti mozku, nýbrž rovněž a vlastně 
především o přirozenosti svaté nemoci. Víceméně stejnou myšlenku pak opakuje bezprostředně poté, co se vyrovná s lidovými představami o svaté nemoci jakožto zásahy bohů. Na začátku svého vlastního výkladu a vysvětlení božské nemoci ř́ká:

4 „Tato nemoc se mi nezdá božštějšsí než ostatní. Má sice přirozenost ( $f y$ sis) jako i jiné nemoci a př́ičinu (profasis) ${ }^{39}$, odkud všechny vznikají (hothen hekasta ginetai), ale jakožto božská co do přirozenosti (fysis) a příčiny (profasis) vzniká z téhož [tj. z týchž př́íčin], z čeho [z jakých] vznikají i ostatní nemoci. ${ }^{40}$ Rovněž je léčitelná, a to neméně než ostatní."41

Co se ovšem myslí tím, že svatá nemoc (jakož i každá jiná nemoc) má přirozenost? Pokud přirozenost znamená něco jako pravou či ideální povahu nějaké věci, pak je sice poměrně jasné, co znamená přirozenost mozku (případně jiného tělesného orgánu), nicméně v případě nemoci to vůbec jasné není. Zatímco totiž pravou povahu či správné fungování nějakého orgánu lze víceméně okamžitě

39 Oproti Grensemannovi a Jouannovi ponechávám spolu s Littrém a Jonesem v textu obrat kai profasin, který je doložen v manuskriptu M (i když byl dlouho především Wilamowitzovou zásluhou upřednostňován rukopis $\theta$, Jouanna toto pojetí problematizuje, srv. Jouanna 2003b, s. LXXIV-LXXXVII).

40 Jones ve své edici vypouští větu $\varphi u ́ \sigma ı v$

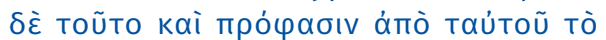
Ө (srv. Hippokratés 1923b, s. 150). Spolu s ostatními editory se však domnívám, že k jejímu vypuštění není důvod.

41

Morb. Sacr. 5,1-5. rozpoznat (pokud orgán nefunguje tak, jak má, má to celou řadu rozpoznatelných důsledků), určit fysis neboli přirozenost nějaké nemoci je možné pouze na základě jejího průběhu. Odlišit různé nemoci nelze pouze na základě jistého symptomu (ba ani celé řady symptomů) v určitém časovém okamžiku, nýbrž pouze na základě dlouhodobějšího pozorování jejich průběhu. Předpokladem léčby je vždy správná diagnóza provedená na základě získaných symptomů z dosavadního průběhu nemoci; pro hippokratovské lékaře bylo navíc velmi důležité stanovení prognózy nemoci (neboli jejího budoucího průběhu). ${ }^{42}$ Jinými slovy, na rozdíl od přirozenosti tělesných orgánů se v případě nemoci prosazuje v koncepci přirozenosti velmi silný vývojový, genetický či diachronní aspekt.

42

Srv. Fischerová 2012, S. 61-62: „Léčba hippokratovského lékaře má však ještě jeden rozměr [...], a to rozměr prognostický. Prognóza představuje $v$ hippokratovské medicíně klíčový pojem, spolu se souvisejícími pojmy krisis a kairos. [...] $\checkmark$ jádru věci tedy leží představa, že nemoc má svůj určitý přirozený průběh, vlastní její fysis: začíná určitým zpưsobem, prochází určitými fázemi, jež je nicméně možno do jisté míry ovlivnit nasazenou léčbou, až dospěje do fáze krisis, tedy do rozhodujícího momentu, k možnému bodu obratu; ve chvíli krize může nemoc ustoupit, nebo naopak pokročit do další fáze. [...] Jestliže pojem krisis reflektuje vlastní průběh nemoci, její přirozenost, byt' $v$ pohledu lékaře, pak pojem kairos představuje v prvé řadě odkaz na lidskou aktivitu, na vhodnou chvíli, kdy je třeba zasáhnout. [...] Rozpoznat kairos ovšem předpokládá znalost minulých stavů, jichž lze užít jako vzorů při usuzování na možný stav príští. Jen tak je totiž možno nemoc pojmenovat - stanovit diagnózu (a v tomto smyslu jsou oba termíny neoddělitelně propojeny) i následující ta deonta, vše, co je třeba činit, a to v pravý čas.“ 
Tento genetický či diachronní aspekt nemusel být do koncepce přirozenosti nijak násilně a svévolně implantován, nebot’ je dán v etymologii samotného řeckého termínu fysis. Substantivum fysis je totiž odvozeno ze slovesa fyein, které v aktivu znamená „plodit, rodit“, zatímco v mediu „růst, vznikat, narodit se“. Protože řecká feminina s koncovkou -sis vyjadřují většinou abstraktní představu procesu pojímaného jako něco konkrétního, ${ }^{43}$ mohla fysis původně znamenat něco jako „růst“. ${ }^{44}$ Nicméně

43

44
Srv. Naddaf 2005, s. 11.

Na tomto místě je třeba upozornit na rozdíl mezi etymologií slova a jeho skutečným, (v konkrétních řečových souvislostech, respektive $v$ písemných dokladech) doloženým významem. Většinou je tento rozdíl intuitivně zcela zřejmý, nicméně v připadě slova fysis ho nelze dostatečně zdůraznit. Problém totiž je, že před polovinou 5. století př. n. l. se v celé dochované řecké literatuře vyskytuje pouze několik málo dokladů jeho použití (konkrétně sedmkrát $v$ nefilosofických textech a jedenáctkrát ve spisech filosofických). Zatímco v nefilosofické literatuře označuje vcelku neproblematicky „vnější podobu“ věci, předsókratici ho pojímali spíš ve významu „pravá povaha“, a tudíž víc zdůrazňovali vnitřní či skryté vlastnosti. A protože není úplně zjevné, co se touto pravou vnitřní povahou přesně myslí, hledají interpreti často oporu v etymologii a jako hlavní význam fysis chápou „růst“, a to nejenom ve smyslu samotného procesu, nýbrž i s ohledem na jeho počátek ( fysis se někdy dokonce interpretuje jako „Vznik“) a výsledný stav, srv. Heidel 1906, s. 97 (zde je uváděna přehledná synoptická tabulka předpokládaných významů fysis vycházejících z její etymologie "růst"; poznamenejme ovšem rovnou, že Heidel do svého výčtu zahrnuje i výskyty fysis u hippokratiků, tj. z druhé poloviny 5. století př. n. l., kdy - jak je zjevné i z našeho výkladu - došlo k jejímu masivnímu použivání a zároveň i k jejímu značnému sémantickému rozšíření); Naddaf 2005, v nejstarších dokladech, které máme textově doloženy, jsou růstové konotace přítomny nanejvýš implicitně či nahodile, ${ }^{45}$ takže rozhodně nepředstavují hlavní význam slova fysis. ${ }^{46}$ Jinými slovy, kromě základního významu „pravá či ideální povaha“ je pro fysis (jak ji v souvislosti s nemocí pojímá náš hippokratovský autor) charakteristický určitý genetický (s její etymologií související) aspekt, který odkazuje k tomu, z čeho daná věc vznikla. Fysis by tedy bylo možné chápat jako pravou povahu či ideální podobu nějaké věci potud, pokud tato věc do své pravé či ideální podoby nějak přirozeně (tj. bez lidských a božských zásahů) dorostla (koneckonců například i mozek se musel do svého přirozeného či

s. 12 (viz následující pozn.). Proti tomuto pojetí srv. například Lovejoy 1909, s. 376: “[...] that as a technical term, and especially in the treatises of the cosmol-

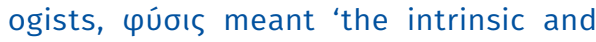
permanent qualitative constitution of things' or, more colloquially, 'what things really are' [...]." O spojení obou významů se snaži například Kočandrle 2008, s. $18-26$.

45 Srv. Hobza 2009, s. 9-22.

46 Opačné pojetí ilustruje velmi názorně například Naddaf 2005, s. 12: "If one considers that all the compounds of the term phusis and its corresponding verb phuo-phuomai conserve the primary meaning of 'growth, growing' throughout antiquity (and, in particular, in the context of vegetation), then it seems clear the fundamental and etymological [zvýraznil P. H.] meaning of the term phusis is that of growth, even if the meaning of the term evolved. It therefore follows from a linguistic analysis of the word that, as an action noun ending in -sis, phusis means the whole process of growth of a thing from birth to maturity." Srv. předchozí pozn. 
zdravého stavu vyvinout z embryonálních zárodků).

Oproti původnímu významu „pravá povaha“ zdůrazňuje autor spisu $O$ svaté nemoci nový etymologicko-genetický aspekt fysis na základě dvojí strategie:

Za prvé vysvětlení svaté nemoci situuje již do jejích údajných embryonálních počátků, kdy se má vyvíjející se mozek očištovat od hlenu. Doslova říká, že svatá nemoc „začíná růst již v embryu" (archetai de fyesthai epi tú embryú ${ }^{47}$; poznamenejme rovnou, že právě z použitého slovesa „růst“ (fyesthai) je etymologicky odvozena fysis. V tomto smyslu lze tedy přirozenost nějaké nemoci chápat jako určitý vzor či mustr sledující její vývoj od počátečních příčin až po konečné stadium. ${ }^{48}$

Za druhé se náš hippokratovský autor snaží přirozenost svaté nemoci co nejvíce přiblížit k její příčině, ba ji s ní dokonce ztotožnit. Pojmy přirozenost (fysis) a příčina (profasis) totiž spojuje prostřednictvím částice kai, kterou lze chápat nejenom ve slučovacím významu „a“, „a zároveň“, ale rovněž v konkretizujícím významu „a to“, „neboli“; ve dvou krátkých pasážích (1 a 4) takto spojuje oba pojmy hned třikrát. Uvědomíme-li si, že příčinu charakterizuje či koncipuje jako to, odkud něco vzniká (a to bud' prostřednictvím adverbia hothen („odkud“), srv. 4, anebo pomocí předložky ex („z“), srv. 2, případně apo („od“), srv. Morb. Sacr. 16,43; 21,1), pak

47 Morb. Sacr. 8,2-3.

48 Například van der Eijk charakterizuje fysis v našem spise doslova jako "a regular pattern of origin (cause) and growth" (Eijk 2005 , s. 49,57$)$. lze mezi příčinou jakožto tím, z čeho něco vzniká (neboli mezi počátkem procesu), a fysis jakožto procesem růstu spatřovat zjevné strukturní podobnosti. Jinými slovy, zdá se, že etymologicko-genetický aspekt umožnil pojímat fysis jako kauzální faktor, ${ }^{49}$ čehož náš hippokratovský autor maximálně využil, když oba pojmy (příčinu i přirozenost) spojil úzkým slučovacím, ba konkretizujícím vztahem, takže se vzájemně doplňují a vysvětlují. ${ }^{50}$ Jak

Sémantická šǐre pojmu fysis s jeho zjevnými kauzálními konotacemi je velmi dobře patrná v jedné pasáži z hippokratovského spisu $O$ vzduchu, vodách a mistech, který byl možná napsán stejným autorem jako spis $O$ svaté nemoci (srv. Jouanna 2003b, s. LXX-LXXIV; Jones se spíš domnivá, že autor spisu $O$ svaté nemoci byl žákem autora spisu $O$ vzduchu, vodách a mistech, srv. Jones 1923b, s. 132). Poté, co autor spisu $O$ vzduchu, vodách a místech, podobně jako autor spisu $O$ svaté nemoci konstatuje, že „žádná nemoc není ani božštější, ani lidštější než jiná“ (Aër 22,9-10), vysvětluje, že „každá z nemocí má vlastní fysis a žádná se neděje bez fysis“ (Aër 22,11-13). Zatímco v prvním připadě označuje fysis především „přirozenou povahu“ nemoci, v druhém znamená spíš „přirozenou přičinu“, respektive „přirozené přičinné působení.

Obrat "přirozenost a prričina“ se zde někdy chápe jako hendiadys. Podle Jouanny takto pojímá spojení obou pojmů napríklad Grensemann, který ho interpretuje jako „natürliche Ursache“ (Grensemann 1968, s. 61), a snad i Jones, který ho překládá podobně jako „natural cause“ (Hippokratés 1923b, s. 139); sám Jouanna ho jako hendiadys ovšem nechápe (srv. Jouanna 2003a, s. 35). Hendiadys je rétorická či stylistická figura, v níž dochází ke spojení (většinou slučovacímu) dvou substantiv, přičemž tímto spojením vzniká nový význam (například „dnem i noci“, „prach a popel“). Spis O božské nemoci patři sice mezi ty hippokratovské texty, které byly určeny k ústnímu veřejnému přednesu, a které jsou proto rétoricky poměrně 
uvidíme hned v následující kapitole IV., geneticko-kauzální konotace jsou sice pro hippokratovské pojetí fysis charakteristické, nicméně i v rámci hippokratovského corpusu je tak úzké, třikrát zdůrazněné spojení mezi přirozeností a př́ičinou výjimečné.

Teprve na tomto pozadí lze porozumět polemickému tónu úryvku 4, respektive 1. Hippokratovský autor zde chce dát jasně na srozuměnou, že žádná nemoc není zpo̊sobena osobním, ba zlovolným božským zásahem či činem, nýbrž že ji lze vysvětlit na základě přirozených faktorů. Každá nemoc má totiž svou vlastní přirozenost neboli přirozený průběh související s (přirozenými) přričinami, které na ni působí. A jak hippokratovský autor zdůrazňuje, právě tyto přirozené faktory a příčiny jsou něčím božským. Proto lze všechny nemoci považovat za stejně božské, a proto jsou - s podobnou mírou úspěšnosti - i léčitelné.

V souvislosti s rozborem Homéra v kapitole I. jsme konstatovali, že určitá základní či intuitivní koncepce př́ičinnosti ( $v$ tom smyslu, že jisté působení vyvolá jistý efekt) je vlastní všem lidem. V hippokratovském pojednání $O$ svaté nemoci se však setkáváme s mnohem propracovanější koncepcí příčinnosti, kdy příčina (profasis) nepůsobí přímo, nýbrž musí být nejprve zprostředkována či zpracována a teprve skrze toto zprostředkování způsobí

důkladně propracovány (takže by zde použití rétorické figury nebylo překvapivé), přesto se domnívám, že se nejedná o hendiadys. Spojení obou pojmů zde totiž neslouží k vytvoření nového významu, nýbrž spíš k jejich vzájemnému doplnění a vysvětlení. nějaký efekt - například teplo jakožto jeden z možných zapříčiňujících faktorů (profasies) božské nemoci nemůže samo o sobě vyvolat bezprostředně epileptický záchvat, nýbrž působí na mozek, $z$ něhož vyteče hlen do cév; hlen následně zablokuje cirkulaci vzduchu $v$ cévách a to vyvolá záchvat; aby ovšem z mozku mohl vytéct hlen, musí být jeho pravá povaha neboli přirozenost (fysis) nějak deformována, respektive musí mít hlenovitý charakter.

Zdá se tedy, že hippokratovský autor nemohl ke své velmi propracované koncepci příčinnosti jakožto komplexní souhře různých podmiňujících se faktorů dospět bez pojmu přirozenosti. Pojem přirozenosti mu totiž umožnil myslet určitý zprostředkující mezičlánek mezi bezprostřední příčinou a výsledným efektem. Jinými slovy, koncepce př́ičinnosti, jak se s ní lze setkat v hippokratovském pojednání $O$ svaté nemoci, předpokládá pojem přirozenosti. Bez pojmu přirozenosti by totiž hippokratovský autor nemohl rozpracovat tak komplexní koncepci příčinnosti, respektive vysvětlit fungování či mechanismus svaté nemoci. V tomto smyslu lze tedy považovat fysis za programové vyjádření tohoto nového komplexního kauzálního působení.

Je příznačné, že tato koncepce přirozenosti a příčinnosti byla rozpracována v kontextu (hippokratovského) lékařství, a nikoli např́íklad v předsókratovské filosofii. Činnost lékaře tkví v léčení nemoci neboli ve znovunastolování zdraví pomocí různých léčebných prostředků; jedná se takřka o paradigmatický př́íklad činnosti, kdy se 
prostřednictvím určité příčiny (tedy léčebného prostředku, at již léku, stravy, či životosprávy) snažíme dosáhnout určitého účinku (zdraví). V lékařství je ovšem velmi časté, že na nějakou nemoc (anebo alespoň skupinu týchž symptomů vypadajících jako určitá nemoc) neúčinkují stejně tytéž léčebné prostředky (někdy účinkují více, někdy méně, jindy vůbec). Nemáme-li tedy za nemocí vidět (iracionální) zásah boha, lze se jen sotva obejít bez jisté zprostředkující koncepce přirozenosti, která nejenže umožní vysvětlit každou nemoc na základě přirozených kauzálních faktorů, nýbrž především pomůže nahlédnout jejich často velmi složitou souhru. Aby mohl lékař úspěšně léčit, musí pochopit tuto komplexní souhru vzájemně se podmiňujících faktorů; jedině tak může nasadit správnou léčbu. Neúčinnost určitých léčebných prostředků při stejné nemoci lze pak vysvětlit prostřednictvím odlišné přirozenosti různých orgánů (respektive deformace jejich přirozenosti), případně odchylkou samotné nemoci od její přirozenosti či běžného průběhu.

\section{LIDSKÁ PŘIROZENOST}

To, že autor hippokratovského pojednání $O$ svaté nemoci pracuje s velmi propracovanou a komplexní koncepcí př́ičinnosti, která je založená na pojmu přirozenosti, je zjevné. Otázka ovšem je, zda se lze s podobnou koncepcí setkat i v jiných spisech hippokratovského corpusu. Jak jsme naznačili, každý lékař musí - přinejmenším implicitně - pracovat s poměrně složitou či komplexní koncepcí příčinnosti založenou na tom, že bezprostřední příčiny jsou nějak zprostředkovány tělesnými reakcemi. Proto lze očekávat, že i v ostatních hippokratovských spisech bude přítomna podobná komplexní teorie příčinnosti úzce související s koncepcí přirozenosti. Abychom to mohli ověřit, není třeba zkoumat, jak je v nich pojímána samotná příčinnost, nýbrž stačí, když v nich bude hrát důležitou roli fysis (kterou lze - jak jsme viděli - samu o sobě považovat za komplexní kauzální faktor).

Již letmý pohled na ostatní hippokratovské spisy ukazuje, že v nich pojem přirozenosti hraje klíčovou roli, a to často dokonce mnohem zásadnější než v pojednání $O$ svaté nemoci. Zatímco autor tohoto pojednání používal pojem fysis víceméně pouze ve dvou základních významech, jednak jako přirozenost mozku (respektive nějakého tělesného orgánu) a jednak jako přirozenost nemoci, v dalších hippokratovských spisech má tento pojem mnohem širší škálu použití, z níž nejdůležitější a pro hippokratovské lékařství i nejcharakterističtější je pojem přirozenost člověka či lidská přirozenost, případně přirozenost těla (vzhledem k tomu, že hippokratovští lékaři nahlíželi na člověka především z hlediska zdraví těla, není pro ně přirozenost těla víceméně ničím jiným než lidskou přirozeností).

Jak hippokratovští autoři chápali přirozenost člověka? Jednu z nejpregnantnějších a nejznámějších formulací toho, co je to lidská přirozenost, lze nalézt ve stejnojmenném hippokratovském spise, totiž $O$ přirozenosti člověk $a^{51}$ :

51 Tento spis bývá datován do posledních desetiletí 5. století př. n. l., srv. Jones 1923a, s. XXVII-XXVIII. 
5 „Lidské tělo v sobě obsahuje krev, hlen, žlutou a černou žluč. Ty také tvoří přirozenost těla (fysis tú sómatos) a způsobují nemoci a zdraví. Tělo je zdravé nejvíce tehdy, když se tyto štávy chovají přiměřeně (metriós) co do své vzájemné směsi (krésis), účinnosti (dynamis) a množství (pléthos) a když jsou nejvíce smíchány (memigmena). Nemocné je zase tehdy, když se některá z nich vyskytuje v menší nebo větší míře nebo se v těle vyskytuje odděleně (chóristhé) a není promíchána (mé kekrémenon) se všemi ostatními. “52

Pro naše zkoumání není ani tak důležité, z kolika a jakých tělesných štáv je lidská přirozenost (či přirozenost těla) přesně konstituována, jako spíš to, že je chápána jako směs několika základních tělesných konstituentů. ${ }^{53}$

De nat. hom. 9,1-9.

53

Hippokratovské lékařství se běžně spojuje s představou čtyř základních tělesných štáv: krve, hlenu, žluté a černé žluči. Nicméně v corpusu hippokratovských spisů je tato takzvaná humorální teorie ojedinělá, vyskytuje se hlavně ve spise 0 přirozenosti člověka. Zásluhu na tom, že začala charakterizovat hippokratovské lékařství jako takové, má především Galén, který ji připsal samotnému Hippokratovi (domníval se totiž, že spis $O$ prirozenosti člověka byl napsán Hippokratem, připadně jeho zetěm Polybiem) a který ji přijal za vlastní. Tato hippokratovsko-galénovská humorální teorie představovala dominantní lékařské paradigma až do začátku novověku. V samotných hippokratovských spisech hovoři někteři autoři pouze o dvou štávách, hlenu a žluči (například autor spisu o svaté nemoci), někdy o třech. Autor spisu O starém lékařství se zase domnívá, že člověk se skládá z tisíců (myria) různých štáv (VM 14,31-35). Ve spise O životosprávě se nehovoři o štávách, ale o dvou
Nebylo by ovšem správné, kdybychom těžiště hippokratovské koncepce spatřovali především v redukci lidské přirozenosti na základní konstituenty. Hippokratovského lékaře zajímají především jejich vzájemné poměry, nebot' právě ty rozhodují o zdraví a nemoci. Má-li totiž úspěšně léčit, musí uvádět (čtyři) základní štávy do správných vzájemných poměrů a vytvářet $\mathrm{z}$ nich správnou směs. A protože nemoc je něco patologického či nepřirozeného, je lidská přirozenost zdravým stavem těla neboli správně či harmonicky uspořádanou směsí základních konstituentů. ${ }^{54} \mathrm{~V}$ tomto smyslu představuje lidská přirozenost normativní koncepci, na základě jejíž znalosti lékař léčí a již se snaží v nemocném znovu vytvořit.

Tento normativní aspekt lidské přirozenosti, který se lékař snaží v nemocném znovunastolit, je velmi názorně

základních živlech, ohni a vodě (Vict. I,3,3-4). Srv. Fischerová 2012, s. 52-54; Bartoš 2008, s. 18-19.

54 Srv. Bartoš 2008, s. 10-11: „Podobně jako dnes i v antice bylo lékařství chápáno jako umění, jehož cílem je pomáhat člověku zbavit se nemocí, které se již projevily, a předejít těm, které mohou teprve prijít. Nemoc byla vnímána jako patologický, tj. nepřirozený stav, který člověku nejenom neprospívá, ale prímo mu škodí. [...] Jak dosvědčují tyto a mnohé další pasáže, přirozenost je v kontextu hippokratovského lékařství chápána především jako přirozenost člověka, a to zejména zdravého člověka. Normativní koncept přirozeného, zdravého stavu je nutným předpokladem jakékoli lékařské teorie, a proto nedílnou součástí tehdejšího lékařství byl i výzkum lidské přirozenosti.“ K údajné prioritě přirozenosti člověka srv. pozn. 38. 
vyjádřen $\mathrm{v}$ jiném hippokratovském spise - ve spise $O$ životosprávě55.

6 „Tvrdím, že ten, kdo chce správně pojednat o lidské životosprávě, musí nejdříve znát (gnónai) a rozpoznat (diagnónai) přirozenost člověka (fysis anthrópú) jako celku. Musí znát, z jakých původních částí se skládá, a také rozpoznat, jakými z nich je ovládána (kekratétai). Pokud by totiž neznal její původní složení, nebyl by schopen poznat, co z jednotlivých částí vzchází; pokud nerozpozná, co je v těle vládnoucí (to epikrateon), nebude s to poskytnout člověku to, co je mu prospěšné (ta symferonta). ${ }^{\text {"56 }}$

Aby lékař mohl léčit, respektive stanovit správnou životosprávu, musí mít vědění o lidské přirozenosti. Musí nejenom znát, z jakých základních konstituentů je složena (na rozdíl od spisu O prirozenosti člověka se autor pojednání $O$ životosprávě domnívá, že člověk se skládá ze dvou základních živlů, ohně a vody), ale hlavně musí u pacienta přesně rozpoznat vzájemné poměry těchto základních konstituentů. Teprve poté, co rozpozná, který živel převládá, může stanovit léčbu, respektive takovou životosprávu, která oba živly přivede $\mathrm{k}$ jejich přirozené rovnováze, a tím opět zajistí zdraví. Vzhledem k tomu, že oheň a voda souvisejí se dvěma páry

Tento spis se většinou datuje do konce 5. století př. n. l., byṫ nelze úplně vyloučit začátek 4. století př. n. l., srv. H. Bartoš 2012, s. 454-455.

Hippokratés 2012 (přel. H. Bartoš), s. 458; Vict. 1,2,1-10. protikladů suché-vlhké a teplé-studené (oheň je suchý a teplý, voda vlhká a studená), konstruuje hippokratovský autor svou dietetickou terapii na poznání, že různé součásti životosprávy (at’ se již jedná o pokrmy, nejrůznější aktivity, roční období atd.) mohou lidské tělo bud' vysušovat, nebo zvlhčovat či zahřívat, nebo ochlazovat. Jinými slovy, dietetická terapie uvede převládající živel opět do rovnováhy. Je zjevné, že takto koncipovaná lidská přirozenost předpokládá poměrně složitou a komplexní teorii příčinnosti. Kromě toho, že lékař musí znát vlastnosti veškerých dietetických složek (pokrmů, tělesných aktivit, ročních dob, větrů, věku atd.) co do jejich základních kvalit suché-vlhké a teplé-studené, musí vědět, na co a jak ta která dietetická složka v lidském těle působí, aby vyvolala kýžený efekt, a převládající živel tak mohl být postupně uveden znovu do přirozené rovnováhy.

I když se autoři spisů $O$ přirozenosti člověka a $O$ životosprávě rozcházejí v názorech ohledně počtu a druhu základních tělesných konstituentů, jejich pojetí lidské přirozenosti je podobné. Oba totiž lidskou přirozenost konstruují do značné míry normativně jako harmonickou směs několika málo základních konstituentů (at’ se již jedná o tělesné štávy, či živly). Avšak například autor spisu $O$ starém lékařství takové pojetí lidské přirozenosti odmítá, nebot’ se zakládá pouze na několika málo konstituentech - navíc postulovaných v rámci logické úvahy (srv. hypothesin hypothemenoi tó logó). ${ }^{57}$ Za příklady takových spekulativních 
konstituentů uvádí teplo, chlad, vlhko a sucho, tedy ty kvality, které představují základ lidské přirozenosti u autora spisu O životosprávě. Problém s postulováním malého počtu tělesných konstituentů (at' už jsou dva, či čtyři) spatřuje autor pojednání $O$ starém lékařství především v tom, že se tak značně zužuje možnost kauzálního vysvětlení; odlišné jevy jako různé nemoci či smrt se totiž musejí vysvětlovat pomocí totožných příčin, ${ }^{58}$ což nedává smysl.

I přes tuto kritiku svých současníků ovšem ani autor spisu O starém lékařství nerezignuje na koncepci lidské přirozenosti. ${ }^{59}$ Právě naopak. Avšak na rozdíl od těch, kteří ji redukují na několik málo logicky či spekulativně vytvořených konstituentů a které s jistým despektem označuje jako intelektuály (sofistai) a spojuje je podobně jako Empedoklea s pouhou teoretickou činností (filosofié), je přesvědčen, že lidskou přirozenost lze poznat pouze na základě důkladné lékařské praxe. ${ }^{60} \mathrm{~A}$ je to právě lékařství, které podle tohoto hippokratovského autora umožňuje stanovit, že lidská přirozenost je ovlivňována stravou. ${ }^{61}$ Pokud je strava těžká či nějak nevyvážená, nemusí ji naše přirozenost být schopna zvládnout, což ji může narušit. Její narušení vyvolává bolesti, nemoci, ba smrt. Otázka ovšem je, jak strava na lidskou přirozenost přesně působí, případně co to vlastně lidská přirozenost je, že na ni může strava takto bezprostředně působit.

\footnotetext{
58 VM 1,4-8.

59 Srv. Daneš 2008.

60 VM 20,1-23.

61 VM 3,33-48.
}

7 „V lidském těle je tedy slané, hořké, sladké, kyselé, ostré, nevýrazné a nesčetné množství jiných věcí (alla myria), které mají rozličné vlastnosti co do počtu a síly; když jsou vzájemně promíchány (memigmena) a smíšeny (kekrémena), nejsou zjevné ani nepoškozují organismus, kdykoli se ale něco z toho vyloučí (apokrithé) a vyskytne se samo o sobě, stane se zjevným a zdraví škodlivým. Tak i jídla, která jsou pro nás nevhodná a poškozují člověka, když je pozře, jsou ve všech případech hořká, nesmíšená (akréton) a se silnými účinky, a proto jsme jimi podrážděni, stejně jako tím, co se odlučuje (apokrinomena) v těle."62

Lidská přirozenost je harmonickou směsí nesčetných tělesných štáv, které mají mnohdy stejné vlastnosti jako strava (např́íklad slanost, hořkost atd.). Proto může př́iliš jednostranná či nevyvážená strava v těle posílit tu kterou štávu, která se pak osamostatní či vyloučí (apokrinein) na úkor původní harmonické směsi. A narušení původní harmonické směsi působí potíže a nemoci. Autor pojednání O starém lékařství se sice ostře vymezuje proti svým současníkům, kteří lidskou přirozenost redukovali na několik málo logicky vyvozených konstituentů, a staví proti nim své pojetí lidské přirozenosti založené na nesčetném množství různých štáv (myria), k němuž lze dojít pouze na základě důkladného empiricko-lékařského zkoumání vlivu stravy na člověka, nicméně i jeho pojetí lidské přirozenosti

\footnotetext{
62 Mírně upravený překlad podle Hippokratés 2012 (přel. J. Daneš), s. 374; VM 14,31-45.
} 
vychází z představy harmonické směsi tělesných konstituentů. A pokud jsou tyto nesčetné štávy v lidském těle vzájemně harmonicky promíchány a smíšeny, je člověk zdravý; pokud ovšem dojde k tomu, že se nějaká osamostatní a ze směsi se vyloučí, dojde $\mathrm{k}$ narušení přirozenosti, a tím ke zdravotním problémům. Úkolem lékaře je tedy (podobně jako u většiny hippokratovských autorů) předcházet či napravovat narušenou lidskou přirozenost tím, že aplikuje vhodnou životosprávu (stravu, aktivity, podnebí atd.).

Jestliže se lidská přirozenost zakládá na nespočetném množství různých štáv či prvků, je zjevné, že autor spisu $O$ starém lékařství musí pracovat s poměrně jemnou a propracovanou představou př́ičinnosti, nebot' i nepatrná převaha nějaké vlastnosti ve stravě může narušit harmonickou směs lidské přirozenosti. Může totiž dojít k nadměrné tvorbě nějaké štávy, například hlenu, což může vyvolat celou řadu dalších důsledků, např́íklad bolesti v krku, angínu či zápal plic. ${ }^{63}$ Lékař tedy musí nejenom rozpoznat vlastní příčinu nemoci (například v případě angíny či zápalu plic výtok hlenu do krku), nýbrž především musí být schopen tuto příčinu vyléčit či odstranit (například na základě vhodné diety či životosprávy zabránit tvorbě hlenu). Jinými slovy, lékař musí dokázat sledovat celý řetězec př́íčin a jejich vzájemnou souhru.

\section{ZÁVĔR}

V hippokratovských spisech se lze setkat s velmi propracovanou koncepcí

63

VM 19,18-21. př́ičinnosti, která se neomezuje na pouhé konstatování, že něco působí na něco, nýbrž která předpokládá velmi komplexní a propracovanou souhru nejrůznějších kauzálních faktorů. Aby ovšem hippokratovští autoři mohli vypracovat tuto komplexní koncepci př́činnosti, museli zároveň rozvinout koncepci přirozenosti. Zdá se tedy, že koncepce příčinnosti předpokládá, ba vyrůstá z jejich koncepce přirozenosti. Na tomto místě by bylo samozřejmě možné hned namítnout, že už Mílétané měli hovořit o fysis, ba měli z ní dokonce učinit jeden z hlavních pojmů svého myšlení. Pokud by tomu tak bylo, nebylo by možné předpokládat, že i Mílétané mohli pracovat s nějakou koncepcí příčinnosti, kterou by podobně jako hippokratici zakládali na fysis?

Pomineme-li fakt, že se nám od Mílét’anů nedochovaly žádné přímé zprávy (takže nemůžeme vědět, zda se u nich pojem fysis skutečně vyskytoval, případně v jakém významu), je pravděpodobné, že hippokratici používali fysis v poněkud odlišném smyslu, než v jakém se běžně připisuje Mílétanům či ostatním předsókratikům. Zatímco Mílétané měli - podle běžného přesvědčení - pojímat svět jako souhrn přirozených jevů či dějů, v němž nedochází ke svévolnému zasahování bohů (zhruba v tomto smyslu chápal údajné předsókratovské zkoumání přírody Platón a po něm celá následující tradice, srv. peri fyseós historia $\left.{ }^{64}\right),{ }^{65}$

$$
\begin{aligned}
& 64 \text { Phd. 96a5-9. } \\
& 65 \text { Srv. Naddaf 2005, s. 15: "Although phusis is } \\
& \text { absent from the writings of early Ionians, } \\
& \text { that is, the first philosophic writings, it is } \\
& \text { unanimously accepted today, as it was in } \\
& \text { antiquity, that the concept of phusis was }
\end{aligned}
$$


pro hippokratiky je naopak charakteristické, že ve svém pohledu na svět vyšli z toho, že každá věc má nějakou vlastní přirozenost či pravou povahu. Jak jsme viděli, v hippokratovských spisech znamená fysis především „přirozenost“ neboli „pravou povahu“ jednotlivé věci. O fysis se zde hovoří v souvislosti s lidskými těly (případně jejich orgány), s nemocemi a s některými dalšími faktory, které podle těchto lékařů ovlivňují lidské zdraví (jako jsou například povaha jednotlivých míst, druhy větrů, kvalita vody atd.).

I když se hippokratovští autoři zabývali pouze přirozeností věcí, které souvisejí s nemocemi, nedopustíme se snad přílišného zjednodušení či zobecnění, když řekneme, že z hippokratovského

a creation of Ionian science. It was a creation to the extent the word permitted the Ionians to present a new conception of the world in which natural causes were substituted for mythical ones. [...] In my view, the early lonians did indeed have a comprehensive vision of nature and this vision was reflected in the term phusis."; tamt., s. 63-64: “The word permitted the Ionians to present a new conception of the world in which natural/rational causes/explanations were substituted for mythical ones." Podobně se vyjadřuje i Pohlenz (1953, s. 426): „Der Begriff der Physis ist eine Schöpfung der ionischen Wissenschaft, die in ihm ihr ganzes neues Weltverständnis zusammenfaßte. Der Terminus bezeichnete für sie nicht nur das organische Wachstum von Pflanze und Tier, sondern auch das Ergebnis dieses Prozesses, das durch diesen bestimmte Sosein, in dem sich das ,Wesen vollendet, zugleich aber auch die Kraft, die nach strengen immanenten Gesetzen den Werdeprozeß regelt, im einzelnen wie im großen Kosmos. Auf diesen Begriff gründete sie die Naturwissenschaft, die dem Orient fremd war." Srv. též Kočandrle 2008, s. 11-26; Kočandrle 2010, s. 77-79. hlediska lze svět považovat za souhrn věcí, z nichž každá má nějakou vlastní přirozenost neboli pravou povahu. Pokud svět pochopíme tímto způsobem, můžeme ho sice bezesporu považovat za souhrn jevů či dějů, které se dějí přirozeně (bez zásahu bohů či lidí), a tudíž jako přírodu, nicméně přiznat každé věci přirozenost má mnohem zásadnější a hlubší důsledky než pouhé eliminování svévolných božských zásahů. Jestliže má totiž každá věc určitou přirozenost, je nejenom možné, ale například z hlediska lékařství i nutné přemýšlet o tom, co způsobuje, že se nějaká věc odchýlí od vlastní přirozenosti (respektive o tom, co zapříčinilo daný patologický stav těla), případně o tom, jak dané věci opět navrátit ztracenou přirozenost (jak tělo vyléčit). Jinými slovy, má-li každá věc svou přirozenost, stane se důležitou otázka, co způsobuje, že se něco začne vzdalovat své vlastní přirozenosti. Předpoklad, že každá věc má svou vlastní přirozenost neboli pravou povahu, vede jaksi automaticky k hledání příčin (jakožto faktorů, které jednotlivou přirozenost nějak ovlivňují a formují).

Snad by bylo možné ještě namítnout, že (at' již byl vztah mezi fysis a příčinami jakýkoli) Empedoklés a Anaxagoras museli mít nějakou koncepci příčinnosti (byt nemuseli používat explicitně pojem příčina). Oba totiž předpokládali, že láska a svár, respektive mysl působí na směs prvků; a tímto způsobem vysvětlovali kosmogonický proces, případně obecně dynamiku přírodních procesů. Srovnáme-li však tyto jejich působící principy s hippokratovskou koncepcí příčin, objeví se 
v jejich údajné koncepci příčinnosti určité trhliny. U hippokratovských autorů představuje totiž příčinnost velmi komplexní souhru různých faktorů, které se všechny vzájemně podmiňují, na sebe vzájemně působí a navíc - jakoby imanentně - spadají do oblasti fysis (at'již pochopené jako přirozenost, či příroda). Naproti tomu láska a svár u Empedoklea či mysl u Anaxagory působí jaksi zvnějšku. Vlastně nejsou ani součástí vysvětlovaného procesu. Jejich působení je tak vlastně pouze jednosměrné - v tom smyslu, že s daným procesem nijak vzájemně neinteragují. Lze je tedy považovat za jakési katalyzátory, které daný proces sice vyvolají, avšak samy jím nejsou nijak poznamenány či pozměněny. ${ }^{66}$

Otázka ovšem je, nakolik lze takové vnější činitele považovat za skutečné př́ičiny. A i když její zodpovězení záleží do značné míry pouze na definici př́íčinnosti, můžeme každopádně konstatovat, že Empedokleovy a Anaxagorovy působící principy se podobají spíš homérským bohům než propracované hippokratovské koncepci příčinnosti. Podobně jsou homérští bohové sice za daný proces zodpovědní (aitioi), nicméně ani oni nejsou součástí procesu, který vyvolávají, ani jím nemohou být nijak poznamenáni či pozměněni. V hippokratovském pojetí však naproti tomu dochází k velmi komplexní souhře na sebe působících a vzájemně se podmiňujících faktorů, kdy jedna věc sice zapříčiňuje druhou, ale zároveň může být svým působením sama proměňována.

Podíváme-li se tedy na Empedokleovo pojetí lásky a sváru, respektive Anaxagorovu mysl prizmatem komplexní a propracované hippokratovské koncepce příčinnosti, nelze než konstatovat, že u Empedoklea a Anaxagory lze sice hovořit o příčinách, nicméně v tak obecném, širokém či triviálním smyslu, že oběma myslitelům lze jen sotva přiznat systematický či reflektovaný zájem o hledání příčin, natož vypracování nějaké explicitní teorie př́ičinnosti (jako tomu bylo u hippokratovských autorů). Jejich chápání příčinnosti se tedy příliš neliší od běžných lidových nereflektovaných představ, s nimiž jsme se setkali již u Homéra a podle nichž nelze například očekávat, že sklidíme úrodu, aniž bychom zaseli, případně že může pršet, když na obloze nejsou mraky.
I když to Empedoklés nikde explicitně neříká, lze si jen sotva představit, že by láska a svár byly nějak ovlivňovány směsí kořenů, na niž působí. Naproti tomu Anaxagoras o mysli explicitně říká, že se s ničím nemísí a že je nejjemnější a nejčistší ze všech věcí (srv. DK 59 B 12). 


\section{ZKRATKY}

\section{Aristotelés}

Met.

$D K$

\section{Metaphysica}

Diels, H., Kranz, W. (1969). Die Fragmente der Vorsokratiker. 6. Aufl. Zürich: Weidmann.

\section{Hippokratés}

Aër

De nat. hom. Morb. Sacr. Vict. $V M$
De aëribus, aquis et locis

De natura hominis De morbo sacro De victu De vetere medicina

\section{Herodotos}

Hist. Historiae

Homér

Il. Ilias

LSJ Liddell, H. G., Scott, R., Jones, H. S. (1996). Greek-English Lexicon. Oxford: Oxford University Press.

Platón

Phd.

Phaedo

\section{BIBLIOGRAFIE}

Aristotelés (2008). Metafyzika (přel. A. Kř́íž). Praha: Rezek.

Bartoš, H. (2008). „Koncept lidské přirozenosti $\mathrm{v}$ hippokratovském lékařství“. In: L. Chvátal, V. Hušek (eds.), „Přirozenost“ ve filosofii minulosti a současnosti. Brno: Centrum pro studium demokracie a kultury, s. 9-23.

Bartoš, H. (2012). „O životosprávě I. Úvod“. In: Hippokratés, Vybrané spisy, I (eds. H. Bartoš, S. Fischerová). Praha: OIKOYMENH, s. 417-456.

Burge, E. L. (1971). „The Ideas as Aitiai in the Phaedo". Phronesis 16, s. 1-13.

Daneš, J. (2008). „Kritická diskuse o pojmu lidské přirozenosti $\mathrm{v}$ hippokratovském spisu Peri archaiés iétrikés“. In: L. Chvátal, V. Hušek (eds.), „Přirozenost“ ve filosofi minulosti a současnosti. Brno: Centrum pro studium demokracie a kultury, s. 24-33.

Diels, H., Kranz, W. (1969). Die Fragmente der Vorsokratiker. 6. Aufl. Zürich: Weidmann.

Dodds, E. R. (2000). Řekové a iracionálno. Praha: OIKOYMENH.

Eijk, P. J. van der (2005). „The 'theology' of the Hippocratic treatise On the Sacred Disease“. In: P. J. van der Eijk, Medicine and Philosophy in Classical Antiquity: Doctors and Philosophers on Nature, Soul, Health and Disease. Cambridge: Cambridge University Press, s. 45-73. 
Fischerová, S. (2012). „Úvodní studie“. In: Hippokratés, Vybrané spisy, I (eds. H. Bartoš, S. Fischerová). Praha: OIKOYMENH, s. 15-146.

Fischerová, S., Beran, A. (eds.) (2012). Medicína mezi jedinečným a univerzálním. Červený Kostelec: Pavel Mervart.

Frede, M. (1987). „The Original Notion of Cause“. In: M. Frede, Essays in Ancient Philosophy. Minneapolis: University of Minnesota Press, s. 125-150.

Grensemann, H. (1968). Die hippokratische Schrift „Über die heilige Krankheit". Berlin: Walter de Gruyter.

Hankinson, R. J. (1998). Cause and Explanation in Ancient Greek Thought. Oxford: Clarendon Press.

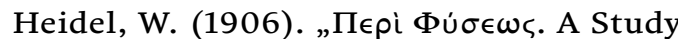
of the Conception of Nature among the Pre-Socratics". Archiv für Geschichte der Philosophie 19, s. 333-379.

Hippokratés (1849). Oeuvres complètes d'Hippocrate, VI (ed. a přel. É. Littré). Paris: J. R. Baillière.

Hippokratés (1923a). Hippocrates, I (přel. W. H. S. Jones). London: Heinemann.

Hippokratés (1923b). Hippocrates, II (přel. W. H. S. Jones). London: Heinemann.

Hippokratés (1958). Hippocrates, IV (přel. W. H. S. Jones). London: Heinemann.
Hippokratés (2003). La maladie sacreé (ed. J. Jouanna). Paris: Belles lettres.

Hippokratés (2012). Vybrané spisy, I (eds. H. Bartoš, S. Fischerová). Praha: OIKOYMENH.

Hobza, P. (2009). „Fysis u předsókratikü“. Aither 1, s. 9-22.

Hobza, P. (2015). „Je skutečně zjevné, že Aristotelovi předchůdci hovořili o př́ičinách? (Met. 983b3)“. Aither 13, s. 46-55.

Jones, W. H. S. (1923a). „General Introduction“. In: Hippokratés, Hippocrates, I (přel. W. H. S. Jones). London: Heinemann, s. VII-LXIX.

Jones, W. H. S. (1923b). „The Sacred Disease. Introduction“. In: Hippokratés, Hippocrates, II (přel. W. H. S. Jones). London: Heinemann, s. 129-137.

Jones, W. H. S. (1958). „Introduction“. In: Hippokratés, Hippocrates, IV (přel. W. H. S. Jones). London: Heinemann, s. IX-LVIII.

Jouanna, J. (1984). „Rhétorique et médicine dans la collection hippocratique". Revue des Études Grecques 97, s. 26-44.

Jouanna, J. (2003a). „Notes complémentaires". In: Hippokratés, La maladie sacreé (ed. J. Jouanna). Paris: Belles lettres, s. 35-138. 
Jouanna, J. (2003b). „Notice“. In: Hippokratés, La maladie sacreé (ed. J. Jouanna). Paris: Belles lettres, s. VII-CXXXIII.

Kirkwood, G. M. (1952). „Thucydides’ Words for 'Cause'". The American Journal of Philology 73, s. 37-61.

Klouda, J. (2012). „O umění. Úvod“. In: Hippokratés, Vybrané spisy, I (eds. H. Bartoš, S. Fischerová). Praha: OIKOYMENH, s. 291-309.

Kočandrle, R. (2008). Fysis iónských myslitelů: rozprava nad peripatetickou dezinterpretací. Červený Kostelec: Pavel Mervart.

Kočandrle, R. (2010). Anaximandros z Mílétu. Červený Kostelec: Pavel Mervart.

Liddell, H. G., Scott, R., Jones, H. S. (1996). Greek-English Lexicon. Oxford: Oxford University Press.

Lloyd, G. E. R. (1979). Magic, Reason and Experience. Studies in the Origin and Development of Greek Science. Cambridge: Cambridge University Press.
Lonie, I. M. (1981). The Hippocratic Treatises "On Generation", "On the Nature of the Child", "Diseases IV": A Commentary. Berlin: Walter de Gruyter.

Lovejoy, A. O. (1909). „The Meaning of

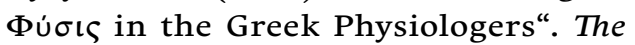
Philosophical Review 18, s. 383-396.

Naddaf, G. (2005). The Greek Concept of Nature. Albany, NY: State University of New York Press.

Platón (1994). Faidón (přel. F. Novotný). Praha: OIKOYMENH.

Pohlenz, M. (1953). „Nomos und Physis“. Hermes 81, s. 418-438.

Rawlings, H. R. (1975). A Semantic Study of Prophasis to 400 B.C. Wiesbaden: Steiner.

Thein, K. (2012). „Lidská přirozenost a její rozmanitost v Corpus Hippocraticum“. In: S. Fischerová, A. Beran (eds.), Medicína mezi jedinečným a univerzálním. Červený Kostelec: Pavel Mervart.

Vlastos, G. (1969). „Reasons and Causes in the Phaedo“. The Philosophical Review 78, s. 291-325. 